\title{
Non-Human Primates: Model Animals for Developmental Psychopathology
}

\author{
Eric E Nelson ${ }^{1}$ and James T Winslow ${ }^{\star, 1,2}$ \\ ${ }^{1}$ Mood and Anxiety Disorders Program, Intramural Research Program, National Institute of Mental Health, Bethesda, MD, \\ USA; ${ }^{2}$ Non-Human Primate Neurobiology Research Core, Intramural Research Program, National Institute of Mental Health, \\ Bethesda, MD, USA
}

Non-human primates have been used to model psychiatric disease for several decades. The success of this paradigm has issued from comparable cognitive skills, brain morphology, and social complexity in adult monkeys and humans. Recently, interest in biological psychiatry has focused on similar brain, social, and emotional developmental processes in monkeys. In part, this is related to evidence that early postnatal experiences in human development may have profound implications for subsequent mental health. Non-human primate studies of postnatal phenomenon have generally fallen into three basic categories: experiential manipulation (largely manipulations of rearing), pharmacological manipulation (eg drug-induced psychosis), and anatomical localization (defined by strategic surgical damage). Although these efforts have been very informative each of them has certain limitations. In this review we highlight general findings from the non-human primate postnatal developmental literature and their implications for primate models in psychiatry. We argue that primates are uniquely capable of uncovering interactions between genes, environmental challenges, and development resulting in altered risk for psychopathology.

Neuropsychopharmacology Reviews (2009) 34, 90-105; doi: I0. I038/npp.2008. I50; published online 17 September 2008

Keywords: rearing; mood; anxiety; social; depression; amygdala

\section{INTRODUCTION}

Recent advances in genetic technology hold great potential for advancing our understanding and treatment of psychiatric conditions. It is also clear that many non-genomic factors interact with genotype in the progress of psychopathology (Tsankova et al, 2007). A reductionist approach based on genotype alone will likely not suffice to explain the development of much mental illness (Eichler and Zimmerman, 2008). Non-human primate models are poised to provide unique access to highly complex interactions between genes and early developmental experiences, and to the subsequent emergence and expression of mental illness in adulthood. A major challenge for the future will be to identify how a specific genotype or combination of genes might interact differently with a specific environment or life history to increase or decrease the likelihood of subsequent psychopathology.

${ }^{*}$ Correspondence: Dr JT Winslow, Non-Human Primate Neurobiology Research Core, 16701 Elmer School Road, NIHAC 110/121, Dickerson, MD 20842, USA, Tel: + 301451 2198, Fax: + 301480 4626,

E-mail: jameswinslow@mail.nih.gov

Received 19 March 2008; revised 11 July 2008; accepted 2 August 2008
We assert that a critical window for this interaction occurs during postnatal development. This is distinct from intriguing evidence of prenatal sensitivities to environment that we will not address here due to space limits (Coe and Crispen, 2000; Coe et al, 2002, 2003; Francis et al, 2003). Although postnatal development had at one point been considered a time of nervous-system plasticity with a broad capacity to 'absorb' significant injury (Bower, 1990), it has also become evident that adverse postnatal experiences can both confer significant risk for as well as protection against the subsequent emergence of psychopathology (Nemeroff, 2004; Pine and Cohen, 2002). We believe that the nonhuman primate provides a unique opportunity to examine the different mechanisms that confer either risk or resilience during development and a method of harnessing these sensitivities to protect individuals against the emergence of mental illness throughout life. A growing number of studies have now begun to look at the persistent effects of early experience on emotional development and the interaction of experience with candidate genes (Barr et al, 2004b, c, 2008; Dempster et al, 2007; Newman et al, 2005; Spinelli et al, 2007; Strauss et al, 2005). Although predominantly association ( $v s$ linkage) studies, these provide a broad arsenal of candidate genes for considera- 
tion including serotonin transporter polymorphisms, opioid, dopamine, and peptide mutations.

In this review we will focus on efforts to understand the consequence of postnatal experiences that have been used to model developmental aspects of psychopathology in nonhuman primates.

\section{Why are Primate Models Important to Biological Psychiatry?}

Primate models of mental processes have served psychiatry for decades particularly in the domains of higher cognitive processes, and auditory and visual image processing. These models have focused on primates to further the understanding of complex neurocognitive processes due to the similar complexities of the adult human and monkey brains. Advances in vivo imaging technologies continue to inform these comparisons (Logothetis, 2008; Orban et al, 2004). As with complex neurophysiological processes, the similarity between human and non-human primates is evident in many features that are particularly relevant for psychiatric evaluation. Humans share a great deal of evolutionary history with non-human primates. Most non-human primate species live in complex social environments, which require sophisticated social cognition and behavior to recruit social support, alliance formation, and recognition of emotional displays (see for example, Maestripieri, 2007). Many psychiatric diseases are defined by their interference with normal social interactions, associated with impaired social and cognitive skills, and are in turn exacerbated when social support is inadequate or unreliable (Lam and Rosenheck, 1999; McCorkle et al, 2008; McManus, 1996).

To understand how psychiatric illnesses are affected by and expressed in a complex social development, nonhuman primates are uniquely appropriate model animals. Many non-human primates share with humans a prolonged developmental period between birth and adulthood in which socialization is progressively focused from parental care to adolescent independence and peer politics. This protracted period of development provides an opportunity for environment and experience to redirect, exacerbate, or attenuate gene-dependent pathologic tendencies. Understanding how and when these interactions are most influential in primates will likely inform the search for similar relationships in humans.

\section{Practical Limitations and Constraints}

For reasons discussed above non-human primate models of psychopathology have been important to psychiatric research for many years (Ellinwood et al, 1973; Thorne, 1972). However, relative to both rodent-based models and direct human studies, psychiatric research using primates remains comparatively underrepresented in the literature. There are several reasons for this: (1) primates are much more expensive to recruit, care for, and house than rodents (and perhaps humans); (2) primates are difficult and labor intensive to handle safely; (3) the prolonged period of development for many primates, although attractive for some applications, can be daunting for others; for example, a developmental study which takes several days to complete in rodents can take several years in primates; (4) there are important ethical and legal concerns and constraints which must be addressed to initiate non-human primate studies (Swiss Committee on Animal Experiments, 2006; Eudey, 1981; Quigley, 2007).

\section{Species Selection and Species Differences}

Efforts to develop non-human primate models of developmental processes in psychiatry have focused in large part on studies of old world primate species, primarily Macaque species (eg rhesus) and to a lesser extent Papio (eg baboon), or Cercopithecus (eg vervet). However, there have been, and continue to be, elegant and very productive efforts to examine similar questions in several new world species, particularly Callithrix (marmoset; Pryce et al, 2004), Cebus (capuchin; Weaver and de Waal, 2003), and Saimiri (squirrel monkeys; Parker et al, 2007). These latter species offer some distinct practical advantages in terms of husbandry and handling. Furthermore, they offer unique behavioral, endocrinological, and neuroanatomical features, which make them quite attractive for specific research questions. For example, marmoset monkeys form monogamous, biparental social relationships and frequently birth twins. This latter feature, along with a relatively short gestation and rapid maturation make the marmoset an attractive candidate for gene-environment interaction studies and conceivably for genetic manipulation. Caution must nevertheless be taken to appreciate that significant species differences do exist both between humans and nonhuman primates (Pryce, 2008) and among the many nonhuman primate species studied.

However, the cost of new world monkeys is that they are one step further away from humans than old world species. These differences are likely to influence the generalizability of findings between species - certainly between new world and old world monkeys - but even between more closely related old world species such as bonnet and rhesus macaques and ultimately between non-human and human species. For example (Pryce, 2008) compared the ontogeny of expression of corticosteroid genes in several new world and old world monkey species and described significant species differences. Pryce suggests that unique expression levels of genes for corticosteroid receptors at the time of an early-life stress will determine what that experience's effect will be on the long-term development of the individual. This will depend on its species, what brain-region was expressing the gene, and the receptor-type specificity. There is also evidence that some genetic polymorphisms (eg 5HTTPR) with demonstrated effect on emotionality and behavior in humans are unique to old world monkey species and may not occur spontaneously in new world monkeys. Conse- 
quently their role in development may not be well modeled in new world monkeys (Lesch et al, 1997).

Nevertheless, induction of mutations in new world monkeys, for example using lentiviral delivery techniques would likely be very instructive-much like strategic mutations in transgenic mice and rats have been for several decades. Furthermore these mutations would be expressed in species capable of highly complex social relationships. Efforts already initiated in rhesus monkeys have demonstrated both the promise as well as the constraints of this approach in old world monkeys (Yang et al, 2008).

Any animal model of a psychopathology must be viewed as an approximation whose value depends on its capacity to 'reconstruct' the etiology and pathophysiology of a disease (Lipska and Weinberger, 2000). Although non-human primates display, under specific circumstances, behavioral syndromes comparable to human depression and anxiety, other disorders such as schizophrenia and autism do not appear to occur spontaneously and may depend on the expressions of speciesspecific behaviors. Furthermore, even when some aspects of a psychopathologic syndrome are present in a primate model, certain aspects - especially those that rely on linguistic processes - may not be present at all. Thus these models are at best only a proxy for a human disease state.

\section{ADVERSE REARING AND SOCIAL EXPERIENCE MODELS}

The pioneering studies of Harry Harlow demonstrated that early life stress can have profound and long lasting effects on the behavior, affect, and physiology of non-human primates (Harlow et al, 1965). These studies typically involved manipulating the early social environment of an infant monkey and we will refer to these and related methods collectively as adverse rearing. Early applications of these models incorporated rather extreme environmental deprivations (eg total social isolation at birth) in an effort to elicit a fully developed psychopathology such as psychosis, autistic syndrome, or anaclitic depression (Harlow et al, 1965; Harlow and Mc Kinney, 1971; Seay and Harlow, 1965).

Accumulating basic, clinical, and epidemiological evidence support assertions that far more modest early adverse experience (compared to social isolation) may alter risk for subsequent psychopathology and medical illnesses both independent of and in interaction with heritable factors (Barr et al, 2003; Sanchez, 2006). Animal models have provided evidence that the experience of an early traumatic event such as maternal stress or illness, as well as postnatal neglect or abuse can alter behavioral and neuroendocrine responsiveness, brain morphology, central levels of gene expression, and neurochemical markers. These experiences may also alter normal developmental processes that have been implicated in the etiology of psychiatric disorders (Sanchez, 2006).

\section{Naturalistic Rearing Environments and Infant Emotionality}

Studies of spontaneous differences in mothering styles in rats and the consequent alterations in behavioral and neural systems of offspring have recently yielded fascinating insights not only about the effects of experience on developmental outcomes but also on the interaction of experience with genotype through epigenetic processes (Szyf et al, 2007; Weaver et al, 2004).

Efforts to examine spontaneous variation in infant monkey emotional development as a function of natural differences in mothering style or rearing experience have also begun to reveal important relationships. These efforts are however constrained by relatively small effect sizes requiring very large population samples for detection in the absence of provocative stimuli (such as maternal loss). These efforts have further demonstrated that significant research costs and unique research environments are necessary for studies in naturalistic populations (Capitanio et al, 2005; Kinnally et al, 2008; Maestripieri et al, 2006).

Empirical, naturalistic studies of adverse rearing in monkeys are relatively recent and have been limited to a preliminary examination of the causes and consequences of abusive or neglectful mothering styles. These are observed to occur at a low but persistent rate in macaque species and appear to be in part heritable (Maestripieri, 1998, 2005; Maestripieri et al, 2005).

Evidence of persistent changes in brain systems including reduced corticospinal fluid 5HIAA (5-hydroxy-indoleacetic acid) levels well after weaning suggest that primate maternal abuse might offer some important insights about subsequent risk for pathology in affected offspring (Maestripieri et al, 2006; Sanchez et al, 2007). This approach, however, suffers from the difficulties of operationally defining or quantifying both severity and the critical timing of abuse (Carroll and Maestripieri, 1998).

Efforts to examine individual differences in emotionality and neural processes associated with variations in maternal care comparable to the methods used successfully by Michael Meaney and his colleagues (Szyf et al, 2007; Zhang et al, 2006) in rodents are nevertheless being adopted in primate studies (Lyons et al, 2000; Parker et al, 2006; Sanchez, 2006) and are likely to reveal important relationships between the physiology of neonatal development and mental health.

\section{Experimental Models of Adverse Rearing}

Like human infants, most primate species used in models of maternal manipulation such as the old world rhesus and the new world marmoset and squirrel monkeys engage in a great deal of intense infant-parental interaction in early infancy. This typically involves extensive physical contact (eg ventral-ventral contact) and buffering juvenile and adult social interchanges during early maturation. Separating infants from their parents initially elicits an intense, 
acute distress and protest response in both infants and mothers. This reaction typically includes psychomotor agitation, vocalization, and elevated secretion of cortisol (Dettling et al, 2007; Rilling et al, 2001) and the behavioral agitation is quickly resolved when mother and infant are reunited.

Reunion is often associated with compensatory motherinfant ventral-ventral contact and heightened protectiveness. The unrelieved protest response typically progresses to a 'despair' profile including loss of motivation, psychomotor retardation, and persistent alterations of homeostatic processes with protracted separation (Kaufman and Rosenblum, 1967a,b). The emotional progression in infant monkeys following maternal separation has been described as acute distress followed by chronic despair and in many ways models the emergence of mood and anxiety disorders in humans (Bowlby, 1973; Emde et al, 1965; Gilmer and McKinney, 2003; Pryce et al, 2005; Spitz, 1952) and rodents (Bush et al, 2002; Hofer, 1996; Kirsch et al, 2005). Remarkably, behavioral compensation during reunion may yet have potent effects on subsequent adaptation to stress and reunion (Sanchez, 2006).

Parental loss/orphanage rearing - These paradigms represent variations on protocols originally described by Harry Harlow (Seay and Harlow, 1965) and developed by Stephen Suomi (Suomi, 1991, 1997). Typically, infants are removed from their mother shortly after birth, hand raised in a nursery for a few weeks after removal and then housed in small groups or pairs of similarly reared peers. These paradigms are typically referred to as peer rearing or nursery rearing. A variation on this procedure includes a period of 'surrogate-rearing' with an inanimate attachment object in place of peers. Although this orphanage-type rearing is clearly abnormal, it is not at all clear what aspect of the experience produces the persistent alterations in behavior and physiology. Indeed, in some ways the nurseryrearing environment is potentially more predictable and possibly less stressful than life with mom in a complex social group. A recent variation on this paradigm has begun to examine maternal loss at different postnatal ages and preliminary reports suggest that the consequent deficits in behavioral development are qualitatively different depending on the age of loss and fostering (Cameron, 2004). These studies ultimately may help clarify when and what aspect of parental loss is significant and what treatments are most successful (Rutter and O'Connor, 2004).

Repeated separation - These paradigms typically involve repeatedly separating infants from their natal group for relatively short periods (few hours, several days, and up to 3-4 weeks) of time followed by repeated reunions (Clarke et al, 1998; Higley et al, 1991; Sanchez et al, 2005). These paradigms are distinguished by more provocative disruptions of parent-infant contact associated with repeated incidents of the protest, despair, and reunion. The impact of these procedures appears to be further intensified if the schedule of the experiences is unpredictable (Levine, 2000; Sanchez et al, 2005).
Maternal neglect-These paradigms include a protocol described by Leonard Rosenblum and co-workers (Andrews and Rosenblum, 1991; Rosenblum and Andrews, 1994) that involved systematically varying the foraging demands on bonnet monkey mothers, which then required them to spend less time in close contact with their infants to obtain their daily access to food. As with repeated separation, the most provocative foraging demand schedules contained an element of unpredictability (Andrews and Rosenblum, 1991). This latter protocol offered a systematic, naturalistic method to address some of the same questions sought by Maestripieri and co-workers (Maestripieri, 1998) in natural populations. It has the added advantage of being able to stage the neglect in selected animals rather than relying on a low-rate emergence of spontaneous maternal neglect in large social groups.

Several themes have emerged in studies of infants that have been reared under conditions of suboptimal parental care. Complex behavioral abnormalities have consistently been observed in adversely reared monkeys, with the most notable deficits being in social and emotional behaviors. Intriguingly, with some caveats these behavioral outcomes appear to be similar for each of the different types of adverse rearing paradigms, particularly when the experience occurs within the first 6 months of life.

\section{BEHAVIORAL ABNORMALITIES}

Adversely reared monkeys display more aggressive and less affiliative behaviors with peers (Suomi, 1997; Winslow, 2005) and reduced competence in both reproductive and parental behavior (Champoux, 2002b; Suomi, 1997). In spite of the fact that they are more aggressive, adversely reared monkeys are also consistently subordinate in the dominance hierarchy than normally reared monkeys (Bastian et al, 2003). The low dominance status is likely to derive from an inability to form alliances with peers (Winslow, 2005). These socioemotional deficits are likely the result of dysfunction in at least two domains. First, adversely reared monkeys generally appear to respond abnormally to emotionally provocative stimuli. In the social domain this has been characterized as blunted or aberrant affective response to social solicitations or social disengagement (Parr et al, 2002; Wallen, 1996; Wallen et al, 1981; Winslow et al, 2003). These emotional alterations typically emerge during early development and persist, and sometimes intensify, as animals mature (Lutz et al, 2003). In addition to the deficit in systems related to general affective tone, there also appear to be specific deficits in social cognition. These social deficits likely have cumulative effects as animals develop progressively more abnormal social repertoires and associated withdrawal or isolation.

Infants who have not engaged in normal social modeling and dominance related processes from the protected embrace of their mothers' ventrum may not acquire the necessary skills to negotiate social politics or the cognitive 
information required for the appropriate processing of complex social signals (Suomi, 1997; Sanchez, 2006).

This deficit in social cognition may lead to incompetent and provocative social behavior-for example, being inappropriately aggressive, submissive, or affiliative in response to conspecific social solicitations (Anderson et al, 1977). Interestingly, a similar pattern of deficits in social cognitive processes may underlie non-selective hyper-affiliative behaviors often observed in human children who were subjected to institutional privation in early life (Rutter and O'Connor, 2004).

In addition to these marked deficits in social behavior, adversely reared monkeys display several other abnormal behavioral features. Adversely reared monkeys display many more atypical behaviors, including both self-injurious behaviors and motor stereotypies, have a heightened behavioral response to mild stressors, and are much more timid and reticent when faced with novel stimuli (Fahlke et al, 2000; Kraemer et al, 1997; Suomi, 1997; Winslow, 2005). A number of studies have also shown that adversely reared monkeys will consume more alcohol as juveniles and young adults than their normally reared peers (Fahlke et al, 2000; Higley et al, 1998). Interestingly, the alcohol consumption of adversely reared monkeys can be attenuated with antidepressant drug administration (Higley et al, 1998) suggesting that increased alcohol consumption of the adversely reared monkeys may be related to an affective disturbance.

Research on adverse rearing in the past decade has focused in large part on alterations in functioning of the hypothalamic-pituitary-adrenal axis. The goal of these studies has been to identify a reliable change in HPA function, which might serve as a risk factor for adult onset mood or anxiety disorder.

Table 1 is a representative bibliography of three common outcomes observed in juvenile and adult nonhuman primates after experimental disruptions of the mother-infant relationship in early life. These outcomes include both vulnerability and resilience to psychopathological states and also describe deficits in social competence. Experimental manipulations included (1) peer rearing, (2) repeated brief separations from the mother, and (3) both variable foraging and demand and high foraging demand placed on the mother. The species studied included the old world rhesus and bonnet macaques and the new world squirrel and marmoset monkeys.

TABLE 1: Summarizng behavioral and endocrine reactivity findings in mother-infant separation models

\begin{tabular}{|c|c|c|c|c|}
\hline PHENOTYPE & PHYSIOLOGY & TREATMENT & SPECIES & CITATION \\
\hline \multirow{16}{*}{$\begin{array}{l}\text { Psychologically } \\
\text { vulnerable }\end{array}$} & Amygdala $\uparrow$ CRF receptors & Brief repeated separation & Rhesus & Sanchez 2006 \\
\hline & CRF $\uparrow$ in CSF & VFD & Bonnet & Coplan et al. 1996 \\
\hline & & & & Coplan et al. 1998 \\
\hline & Cort $\uparrow$ in infancy, $\downarrow$ in juvenile & Brief repeated separation & Marmoset & Dettling et al. \\
\hline & $\uparrow N E$ in juvenile $\downarrow$ reversal learning & & & 2002a; b; Pryce \\
\hline & & & & et al. 2005 \\
\hline & Cort in infancy, blunted diurnal in & Brief repeated separation & Rhesus & Sanchez et al. 2005 \\
\hline & juvenile & & & \\
\hline & $\uparrow$ insulin resistance and obesity & VFD & Bonnett & Kaufman and \\
\hline & & & & Rosenblum 1967a \\
\hline & Cort in infancy, $\uparrow$ juvenile & Peer rearing & Rhesus & Higley et al. 1992 \\
\hline & १TGF-Betal to stress & VFD & Bonnett & Smith et al. 2001 \\
\hline & $\uparrow N E \downarrow 5-H I A A$ in CSF & Peer rearing & Rhesus & Clarke et al. 1996 \\
\hline & & & & Higley et al. 1992 \\
\hline & $\uparrow$ acoustic startle & Brief repeated separation & Rhesus & Sanchez et al. 2005 \\
\hline & $\uparrow$ alcohol intake & Peer rearing & Rhesus & Barr et al. $2004 a$ \\
\hline \multirow{8}{*}{$\begin{array}{l}\text { Psychologically } \\
\text { resilient }\end{array}$} & $\uparrow$ HPA negative feedback & Brief repeated separation & Squirrel & Lyons et al. 2000 \\
\hline & ( $\downarrow$ ACTH to cort) & HFD & & Parker et al. 2006 \\
\hline & $\downarrow$ cort set point & Peer rearing & Rhesus & Capitanio et al. 2005 \\
\hline & $\uparrow$ prefrontal inhibitory control & Brief repeated separation & Squirrel & Parker et al. 2005 \\
\hline & Cort in infancy, no change & Peer rearing & & \\
\hline & in stress & & & Shannon et al. 2005 \\
\hline & $\downarrow$ Cort to stress & Brief repeated separation & Squirrel & Levine and Mody 2003 \\
\hline & & & & Parker et al. 2006 \\
\hline \multirow{6}{*}{$\begin{array}{l}\text { Socially } \\
\text { dysfunctional }\end{array}$} & $\downarrow$ social competence & Peer rearing & Rhesus & Champoux 2002 \\
\hline & & & & Suomi 1997 \\
\hline & $\downarrow$ social reward & Brief repeated separation & Marmoset & Pryce et al. 2005 \\
\hline & $\downarrow$ dominance & Peer rearing & Rhesus & Bastian et al. 2003 \\
\hline & $\uparrow$ aggression, $\downarrow$ affiliative & Peer rearing & Rhesus & Winslow 2005 \\
\hline & $\downarrow$ oxytocin & Peer rearing & Rhesus & Winslow et al. 2003 \\
\hline
\end{tabular}

Abbrev: Corticotropin releasing factor (CRF); norepinephrine (NE) ; cortisol (CORT); transforming growth factor beta (TGF-beta); 5HIAA (5-hydroxyindoleacetic acid); adrenocorticotropic hormone (ACTH); corticospinal Fluid (CSF); hypothalamic pituitary adrenal axis (HPA) 
Although a number of promising leads have been identified, it remains unclear what (if any) aspect of altered HPA axis or central CRF control of HPA activity represents a strong risk factor for adult mental illness. Also unclear is the cumulative role of altered emotional and social deficits in the emergence of adult pathology. It is likely that both behavioral and physiological processes are important and that integration of these outcomes with information about candidate genotypes represents an important new direction for these studies (Sanchez, 2006).

\section{Can Early Adversity Result in Resilience?}

In contrast to the literature cited above indicating an adverse effect of mother-infant separation on stress reactivity, some early studies of infant-mother separation in rodents reported that experimenter handling and brief bouts of maternal separation may actually be protective for the developing animal (Levine, 2000; Meaney et al, 1996; Parker et al, 2006; Pryce et al, 2005).

In particular, limited handling of infants resulted in increased exploration, reduced anxiety levels, and a blunted HPA response to stress in adult animals. This effect may have been in part due to an increased level of licking and grooming by the mother after reunion (Denenberg, 1999). However, it may also be attributed to a benefit of experiencing mild adversity during early development (Levine, 2000). Intriguingly, this behavioral resilience may be associated with neurogenesis in specific brain areas that have also been implicated in the efficacy of antidepressant treatment (Kozorovitskiy and Gould, 2004; Sahay and Hen, 2008; Thompson et al, 2008).

There is similar evidence that mild developmental adversity may have comparable benefits for some nonhuman primates (Lyons and Parker, 2007). Young squirrel monkeys who are subjected to a mild separation stress at the developmental junction of infancy and adolescence, develop better cognitive flexibility skills, have blunted HPA response to stress, and are more curious and exploratory as young adults than monkeys who have not had this experience (Lyons and Parker, 2007; Parker et al, 2005, 2006). This may be a result of learning to overcome a mild challenge during an important period of developmental transition (Lyons and Parker, 2007).

These particular effects have so far been described primarily in new world monkeys - so the possibility of species differences seems possible. However, it is noteworthy that differences which may be characterized as resilient have also been described in the physiological baselines and alterations in HPA activity of both new world and old world monkey species (Lyons et al, 2000).

Understanding the specifics of whether a stressful experience early in development will lead to susceptibility or resilience remains a challenge for future investigations.

\section{ADVERSE REARING INTERACTS WITH GENOTYPE}

Until recently most studies of the effects of adverse rearing have been conducted without the knowledge of the subjects' genotype, and generally separation from the mother is a robust enough manipulation to alter development across a wide variety of genotypes. However, genotype clearly plays an important role in the role of social support in human psychopathology (Arseneault et al, 2008; Caspi et al, 2003). The interaction between genotype and environment in the ultimate expression of psychopathology is very complex, and is an area where non-human primate research may be uniquely able to make important contributions, especially in the three-way interaction between genotype, environment, and development (Champoux et al, 2002a, b; Kinnally et al, 2008; Newman et al, 2005; Reif et al, 2007).

Hereditary factors appear to play a role in monkey's affect, temperament, and response to early adversity. A recent study in marmosets which takes advantage of the fact that marmosets naturally give birth to twins found that hereditary factors contributed substantially to both the acute and long-term changes in cortisol secretion, social behavior, and response to novelty in monkeys that underwent bouts of maternal separation (Dettling et al, 2007). These hereditary responses may be attributed in part to monoamines. Clarke et al, 1995 demonstrated that levels of the biogenic amines and their metabolites in CSF are highly heritable in rhesus monkeys. This is particularly important for affective disorders because of the role that biogenic amines play in mood regulation and the extensive literature indicating dysfunction in these neuronal systems in adversely reared monkeys. Rhesus monkeys contain a polymorphism in the serotonin transporter gene (Barr et al, 2004c), which is homologous to the serotonin transporter polymorphism in humans and affects bioavailability of serotonin. Infant and juvenile rhesus monkeys that were homozygous for the short form of the (s) allele in the promoter region of the 5-hydroxytryptamine (5-HT) transporter gene (5HTTLPR) were found to consistently show a pattern of anxiety and inhibition in a battery of emotional tests (Bethea et al, 2004; McCorkle et al, 2008). Likewise, cynomolgus monkeys who were categorized as being more stress reactive by ceasing to ovulate in response to mild stressors displayed hypofunctioning of the serotonergic system in response to a pharmacological challenge (Bethea et al, 2005). In monkeys, as in humans, hereditary factors not only contribute to the acute stress response but also affect the long-term developmental consequences of stress. A series of studies has now shown that rhesus monkeys who inherit the short form of the 5HTTLPR and are exposed to adverse rearing exhibit chronically lower levels of serotonin in CSF (Bennett et al, 2002), have a potentiated HPA response to stress (Barr et al, 2004c), and consume more alcohol in a preference test (Barr et al, 2004a) than monkeys who were either homozygous for the long form of 5HTTLPR and underwent adverse rearing or who inherited the short form and did not undergo early adversity. For some of these effects, this interaction may be particularly important for 
TABLE 2: Candidate gene polymorphisms interact with rearing experience in monkeys

\begin{tabular}{|c|c|c|c|}
\hline REFERENCE & POLYMORPHISMS & SPECIES & FINDING \\
\hline Bailey et al. 2007 & DRD4 gene & Vervet & $\begin{array}{l}\text { The association of DRD } 4 \text { and novelty seeking is found in a } \\
\text { nonhuman primate model. }\end{array}$ \\
\hline Barr et al. 2003 & rh-5HTTLPR & Rhesus & $\begin{array}{l}\text { Serotonin transporter gene variation is associated with alcohol } \\
\text { sensitivity in rhesus macaques exposed to early-life stress. }\end{array}$ \\
\hline Barr et al. 2004b & rh-5HTTLPR & Rhesus & $\begin{array}{l}\text { Interaction between seroton in transporter gene variation } \\
\text { and rearing condition in alcohol preference and consumption } \\
\text { in female primates. }\end{array}$ \\
\hline Barr et al. 2004c & rh-5HTTLPR & Rhesus & $\begin{array}{l}\text { Rearing condition and rh5-HTTLPR interact to influence limbic- } \\
\text { hypothalamic-pituitary-adrenal axis response to stress in infant } \\
\text { macaques. }\end{array}$ \\
\hline Barr et al. 2004c & rh-5HTTLPR & Rhesus & $\begin{array}{l}\text { Sexual dichotomy of an interaction between early adversity } \\
\text { and the serotonin transporter gene promoter variant in rhesus }\end{array}$ \\
\hline Barr et al. 2007 & OPRM1 C77G & Rhesus & $\begin{array}{l}\text { macaques. } \\
\text { Association of a functional polymorphism in the mu-opioid }\end{array}$ \\
\hline & & & $\begin{array}{l}\text { receptor gene with alcohol response and consumption in } \\
\text { male rhesus macaques. }\end{array}$ \\
\hline Barr et al. 2008 & OPRM1 C77G & Rhesus & $\begin{array}{l}\text { Variation at the mu-opioid receptor gene (OPRM1)influences } \\
\text { attachment behavior in infant primates. }\end{array}$ \\
\hline Bennett et al. 2002 & rh-5HTTLPR & Rhesus & $\begin{array}{l}\text { Early experience and serotonin transporter gene variation interact } \\
\text { to influence primate CNS function. }\end{array}$ \\
\hline Bethea et al.2004 & rh-5HTTLPR & Rhesus & $\begin{array}{l}\text { Anxious behavior and fenfluramine-induced prolactin secretion in } \\
\text { young rhesus macaques with different alleles of the serotonin } \\
\text { reuptake transporter polymorphism }\end{array}$ \\
\hline Bethea et al.2005 & rh-5HTTLPR & Rhesus & $\begin{array}{l}\text { Serotonin-related gene expression in female monkeys with } \\
\text { individual sensitivity to stress. }\end{array}$ \\
\hline Champoux et al. 2002 & rh-5HTTLPR & Rhesus & $\begin{array}{l}\text { Serotonin transporter gene polymorphism, differential early } \\
\text { rearing,and behavior in rhesus monkey neonates. }\end{array}$ \\
\hline Donaldson et al. 2008 & AVPR1A gene & $\begin{array}{l}\text { Apes (2 rpts) } \\
\text { Monkeys (1 rpt) }\end{array}$ & $\begin{array}{l}\text { Evolution of a behavior-linked microsatellite-containing element in the } \\
5 \text { ' flanking region of the primate AVPR1A gene. }\end{array}$ \\
\hline Giorgiand Rouquier 2002 & $\begin{array}{l}\text { V1RL1 } \\
\text { pseudogene }\end{array}$ & Marmoset & $\begin{array}{l}\text { Identification of V1R-like putative pheromone receptor sequences } \\
\text { in non-human primates.Characterization of V1R pseudogenes in } \\
\text { marmoset, a primate species that possesses an intact vomeronasal organ. }\end{array}$ \\
\hline Heinz et al. 2003 & rh-5HTTLPR & Rhesus & $\begin{array}{l}\text { Serotonin transporter availability correlates with alcohol intake in } \\
\text { non-human primates. }\end{array}$ \\
\hline Heinz et al. 1998 & rh-5HTTLPR & Rhesus & $\begin{array}{l}\text { In vivo association between alcohol intoxication, aggression, } \\
\text { and serotonin transporter availability in nonhuman primates. }\end{array}$ \\
\hline Izquierdo et al. 2007 & rh-5HTTLPR & Rhesus & $\begin{array}{l}\text { Genetic modulation of cognitive flexibility and socio-emotional } \\
\text { behavior in rhesus monkeys. }\end{array}$ \\
\hline Kinnally et al.2008 & rh-5HTTLPR & Rhesus & $\begin{array}{l}\text { Effects of early experience and genotype on serotonin transporter } \\
\text { regulation in infant rhesus macaques. }\end{array}$ \\
\hline Kraemer et al.2008 & rh-5HTTLPR & Rhesus & $\begin{array}{l}\text { Moderate level fetal alcohol exposure and serotonin transporter gene } \\
\text { promoter polymorphism affect neonatal temperament and limbic- } \\
\text { hypothalamic-pituitary-adrenal axis regulation in monkeys. }\end{array}$ \\
\hline Miller et al. 2004 & OPRM1 C77G & Rhesus & $\begin{array}{l}\text { A mu-opioid receptor single nucleotide polymorphismin rhesus } \\
\text { monkey: association with stress response and aggression. }\end{array}$ \\
\hline Miller et al. 2001 & DAT - VNTR & Rhesus & $\begin{array}{l}\text { Single nucleotide polymorphisms distinguish multiple dopamine } \\
\text { transporter alleles in primates: implications for association with } \\
\text { attention deficit hyperactivity disorder and other neuropsychiatric disorders. }\end{array}$ \\
\hline $\begin{array}{l}\text { Miller-Butterworth } \\
\text { et al. } 2007\end{array}$ & rh5-HTTLPR & Fasicularis & $\begin{array}{l}\text { The serotonin transporter: sequence variation in Macaca fascicularis } \\
\text { and its relationship to dominance. }\end{array}$ \\
\hline Newman et al. 2005 & rhMAOA-LPR & Rhesus & Monoamine oxidase A gene promoter variation and rearing \\
\hline Putzhammer et al. 2005 & 5HTTLPR & Rhesus & $\begin{array}{l}\text { experience influences aggressive behavior in rhesus monkeys. } \\
\text { Evidence of a role for the } 5 \text {-HTTLPR genotype in the modulation } \\
\text { of motor response to antidepressant treatment. }\end{array}$ \\
\hline Wendland et al. 2006 & $\begin{array}{l}\text { rh5-HTTLPR } \\
\text { rhMAOA-LPR }\end{array}$ & Rhesus & $\begin{array}{l}\text { Differential functional variability of serotonin transporter and } \\
\text { monoamine oxidase a genes in macaque species displaying } \\
\text { contrasting levels of aggression-related behavior. }\end{array}$ \\
\hline
\end{tabular}

females (Barr et al, 2004a, b), which is an important observation because of the female predominance of affective disorders in humans. Table 2 summarizes numerous studies of the interaction of candidate gene mutations or polymorphisms.

\section{Gene Expression and Gene Regulation Studies}

In addition to understanding the contribution that genotype makes to individual differences in emotional responsiveness, a key, recent question is how the expression of specific genes is affected by the timing of exposure to different stimuli (Levitt, 2003; Sabatini et al, 2007). Studies have shown that at a structural level and even at a neurochemical level human and non-human primate brains continue to undergo regulated developmental changes at least through puberty and likely much longer (Gogtay et al, 2006; Levitt, 2003; Lewis, 1997). At a molecular level developmental changes are occurring in gene expression. Although a tremendously complex problem, some of the normative patterns of postnatal gene expression in non-human primate brain are beginning to be mapped out (Miska et al, 2004; Sabatini et al, 2007). As demonstrated in the 
recent study by Sabatini et al (2007) the developmental pattern of gene expression occurs as an interaction with environmental factors. Therefore studies like this, which focus on mapping developmental gene expression in targeted regions such as the amygdala, may offer important clues as to what aspects of CNS function are particularly sensitive to adverse or potentially therapeutic innervations at specific developmental periods. Sabatini et al (2007) showed that the normative timing of the expression of a gene within the amygdala coincided with a differential behavioral effect induced by removing an infant from the mother at different periods of development. Hence the authors concluded that interaction with the mother during this sensitive period was essential for normal expression of this gene within the amygdala. This study is important not only for the specific results but also because it represents a new approach for describing sensitive or critical periods for gene environment interactions.

\section{BRAIN INJURY MODELS}

Although manipulation of the mother-infant relationship has been the most extensively employed method of studying developmental perturbations in primates, it is not the only one. To understand how different brain systems interact across development, studies using lesions, neuroimaging, and gene expression have been performed at different developmental time points.

Brain injury models in primates seek to examine the potential role of specific brain regions or connections between regions in the expression of emotional or cognitive behavior. This is accomplished by examining loss and/or recovery of function following targeted destruction of selected brain structures of affected animals. This can be an awkward experimental approach. Each animal can be used for only one experiment, the lesion is typically irreversible, and the results are based on loss of function and often difficult to interpret. Interpretation is further confounded by the fact that evaluation often occurs months, sometimes years, after the lesion was produced, during which significant neural and behavioral adaptations likely occur.

Early brain injury studies used relatively nonspecific techniques such as aspiration or electrolytic probes to remove small amounts of tissue in targeted areas. The resulting ablations necessarily affect not only the cell bodies but also fibers of passage and consequently reduce the capacity to describe selective and specific relationships between brain loci and behavioral outcomes (Goulet et al, 1998). Nevertheless, for some questions this approach continues to yield important insights about the pivotal role of limbic and cortical structures in the modulation of emotion, cognition, and social competence (Felger et al, 2007; Machado and Bachevalier, 2003).

A complementary technique involves the application of minute quantities of excitotoxins such as ibotenic acid to target areas. Excitotoxins are selectively taken up into and destroy cell bodies, leaving fibers of passage intact. The precision of both techniques has been significantly enhanced in recent years by use of in vivo brain imaging to guide placement of injections or electrodes (Saunders et al, 1990).

Of particular relevance to psychiatry are efforts to examine the role of damaged cortical and limbic structures in monkeys in the emergence of cognitive and social deficits associated with schizophrenia and autism. These include elegant studies of lesions in the prefrontal cortex, orbitofrontal cortex, hippocampus, and amygdala in both adult (for reviews see Bast, 2007; Chudasama and Robbins, 2006; Murray et al, 2007) and neonatal monkeys (to be detailed below). Not surprisingly, evidence indicates that the same lesion may have very different effects depending on when the lesion occurs, in infancy versus adulthood or different stages of adolescence (Bachevalier and Malkova, 2006).

Early developmental brain lesion research focused on the rapid recovery of function and the remarkable plasticity of the infant frontocortical structures (Goldman, 1976, 1978; Miller et al, 1973). More recently, several investigators have begun to examine persistent alterations in cognitive, social, and emotional behavior associated with neonatal lesions in medial temporal regions including amygdala and hippocampus, or frontocortical structures (Bachevalier et al, 1999; Beauregard et al, 1995; Goursaud and Bachevalier, 2007). These efforts have generally focused on one of two broad psychiatric syndromes: cognitive deficits assessed as models of symptoms for schizophrenia or social deficits comparable to symptoms of autism.

\section{Neurodevelopmental Model of Schizophrenia: Neonatal Hippocampal Lesions}

Informed by persistent and reliable evidence of altered cell biology in the hippocampus and associated prefrontal cortical structures of schizophrenic patients (Heinz et al, 1999), numerous investigators have examined animal models of hippocampal damage (Carr and Sesack, 1996; Jay et al, 1989). Interest has focused on the hypothesis that neonatal disturbances in the development of the hippocampus along with projections to the prefrontal cortex may underlie deficits in cortical functioning in schizophrenia. Findings in rat models demonstrated that early lesions produced relatively modest deficits in juvenile rats but deficits appear to intensify as subjects mature, particularly around the time of puberty. This mimics to some extent the typical ontogeny of the schizophrenia. The range of deficits appears across both cognitive and social behaviors and many appear related to dopaminergic processes and are sensitive to dopamine-based therapeutic treatment (Lipska et al, 1995).

Efforts to translate the rodent model to a primate model have also been productive. Similar to rodents, a neonatal lesion of the hippocampus is associated with relatively modest changes in behavior in the young monkey but with more intense deficits emerging as the animal matures 
(Bachevalier et al, 1990). Also consistent are findings that neonatal hippocampal lesions produce persistent changes in dopaminergic systems, particularly in the striatum as well as evidence of a broader pattern of altered neuronal development in the prefrontal cortex (Bertolino et al, 1997; Heinz et al, 1999; Saunders et al, 1998). Subsequent studies have described rather specific social and emotional deficits characterized by elevated aggression. Cognitive deficits also emerged, typically related to recognition memory whereas other functions appeared to be spared (Bachevalier et al, 1990; Goursaud et al, 2006; Kaldy and Sigala, 2004; Lavenex et al, 2007a,b). These studies have generally demonstrated that early hippocampal damage results in reliable and persistent alterations in frontocortical development and that at least some of these alterations can be moderated by damage to the prefrontal cortex or with dopamine-based treatments of schizophrenia. Consequently, these models have relatively strong face and predictive validity for some symptoms of schizophrenia. Conversely, there is little evidence of comparable brain damage in schizophrenia and strong evidence of a genetic transmission of risk, which together indicates that a brain injury model is not likely to attain strong construct validity for the cause of disease.

\section{Neurodevelopmental Model of Socioemotional Deficit: Neonatal Amygdala Lesions}

Interest in the role of the amygdala in the development of social behavior has a long history (Kling, 1974; Kling and Green, 1967), and studies have detailed a reliable relationship between a damaged amygdala and abnormal adult social behavior. Additional studies suggest that these social deficits are related to difficulties assessing and responding to threatening stimuli. (Thompson, 1981; Thompson et al, 1969, 1977; Thompson and Towfighi, 1976) Evidence of a progressive deficit in social and emotional behavior after selective neonatal injuries to the amygdala was replicated by Beauregard et al (1995), who examined the development of social interactions of monkeys amygdalectomized during the first postnatal month. Their findings indicated that early damage to the amygdala results in progressively profound changes in affective responses and social behavior, and these changes persisted into adulthood.

Based in part on these studies as well as human postmortem and in vivo MRI findings, several clinical investigators have proposed that the amygdala may be a critical component to normal social development and that defects in the amygdala may underlie some symptoms of autism (Baron-Cohen et al, 2000; Brothers, 1990). Subsequent studies have revealed that the development of social behavior does not appear to be specifically impaired in animals with selective, neurotoxin-induced lesions of the amygdala (Bauman et al, 2004a, b). Interestingly, one of the factors which may contribute to different outcomes of early lesion is the postnatal rearing environment. Early studies combined neonatal lesion with peer rearing (ie rearing with age-matched peers without adult animals) wherein social deficits associated with abnormal rearing appeared to be aggravated by brain injury (Amaral et al, 2003). Lesioned neonates who are returned to their mothers and for whom the dyad is then provided additional conspecific socialization opportunities until weaning appear to develop normal social repertoires (Bauman et al, 2004b). Additional analysis suggests that the neonatal lesion does not specifically affect social behavior but does significantly affect processing and interpretation of threatening stimuli including threatening social stimuli (Bauman et al, 2004b). In view of the findings related to the persistent effects of adverse rearing, it seems likely that altered social cognition (ie. misinterpretation of threatening social stimuli) involves the amygdala as well as other cortical structures, and injury results in cumulative effects on social competence. This accumulated deficit in appropriate social experience could also result in altered risk for the emergence of psychopathology (see for example Meyer-Lindenberg et al, 2005).

\section{Reversible Inactivation}

There has been increasing interest in methods that permit reversible inactivation of localized brain regions. These techniques involve infusion of minute quantities of substances that temporarily suppress neural activity from several hours up to much longer, experimenter-determined intervals depending on the mechanism of action. Such methods represent particularly attractive technologies for examining the potential role of targeted areas during specific periods of development.

The most common of these techniques uses the inhibitory properties of the GABA agonist muscimol and has been optimized in studies of visual information processing, (eg Ono and Mustari, 2007) and motor control (eg Desmurget and Turner, 2008) in non-human primates. Recently, this method has been applied to studies of neural systems related to psychological constructs in adult monkeys including reward pathways (Amiez et al, 2006; Wellman et al, 2005) and species-specific vocal behavior (Siebert and Jurgens, 2003).

The feasibility of using reversible inactivation techniques to examine developmental models of psychopathology has been demonstrated in rats by Lipska et al (2002), who described emergence of dopamine hypersensitivity in adult rats whose ventral hippocampus was transiently inactivated as neonates. Similar approaches have not as yet translated to applications in non-human primate social and emotional development. In part, this may be related to the relatively short duration of inactivation provided by acute application of these agents (on the order of several hours) and the likelihood that repeated administration produces permanent damage to sites of interest (Heiss et al, 2005). This may limit their usefulness in an organism whose development is measured in months and years compared to a few days. Nevertheless these techniques may be very useful for examining the progress of functional brain-behavior 
relationships over the course of development using limited repeated testing designs (Bay et al, 2007; Chen et al, 2006). Importantly, new gene-silencing technologies developed in rodents offer an intriguing opportunity in the future to examine localized inactivation over more protracted intervals with exquisite control over timing and targeting of the inactivation (Cryan et al, 2007; Kappel et al, 2007; Kumar et al, 2007; Salahpour et al, 2007).

\section{PHARMACOLOGICAL MODELS}

A number of pharmacological models of psychopathology have been advanced in adult rodents, monkeys and humans. Remarkably, few of these models have been translated into developmental models in either rodents or non-human primates. We define such models by efforts to reproduce symptoms of unique psychiatric conditions by administering drugs, either acutely or chronically.

The most prominent among these models are psychostimulant-induced psychosis and amphetamine sensitization paradigms (Castner and Williams, 2007). Various regimes of amphetamine treatment elicit behaviors that have been variously referred to as psychotomimetic (Sams-Dodd and Newman, 1997), psychotic like (Machiyama, 1992), abnormal (Schlemmer and Davis, 1986), and hallucinatory like (Ellison and Eison, 1983). These behaviors include hypervigilance, abnormal eye tracking, grasping, and checking.

A vigorous research effort has demonstrated that this model shows excellent face validity not only for positive symptoms of schizophrenia but also for persistent cognitive deficits such as altered working memory and social deficits. Similarly, the model successfully predicts the therapeutic efficacies of both conventional dopamine-based and novel antipsychotic treatment. Recent studies have also demonstrated that sensitization treatment strategies depend on the integrity of the prefrontal cortex and produce schizophrenialike alterations in prefrontal cortical cell morphology (Selemon et al, 2007).

A number of studies have also examined the anxiogenic properties of selected drugs in non-human primates, such as $\beta$-carbolines (Weerts et al, 1993; Insel et al, 1988; Vellucci et $a l, 1986$ ) or pentylenetetrazol (Palit et al, 1998) or adrenergic receptor agonists (Rosenblum et al, 1991, 1994; Coplan et al, 1992), to describe good face validity for aspects of anxiety and predictive validity for sensitivity to anxiolytic drugs. Indeed, studies by Rosenblum (Rosenblum et al, 1994) demonstrated that early adverse rearing experience was an important determinant of the sensitivity of individual animals to the anxiogenic properties of drugs. Similarly, Miller and his colleagues (Felger et al, 2007) have recently begun to characterize the depressogenic effects of the cytokine drug interferon A in monkeys.

These pharmacological techniques have, to our knowledge not yet been translated into developmental models of psychopathology in non-human primates. This is not to say that developmental pharmacological methods have not been applied to other disease models in both rodents and primates. Indeed, there is a well-developed descriptive literature detailing potential brain injury, emotional and cognitive deficits associated with pre- and postnatal exposure environmental toxins, pollutants and drugs of abuse in non-human primates (Buse et al, 2003; Haberny et al, 2002; Paule, 2005; Rice, 2000; Wu et al, 2008). These efforts have demonstrated that developmental pharmacological challenges might be well suited to providing discreet, quantifiable stimulation of critical pathways during development, particularly in validated risk models, to examine the potential role of unique neurotransmitter systems in subsequent pathology.

\section{FUTURE DIRECTIONS IN PRIMATE DEVELOPMENTAL PSYCHIATRY}

We see several critically important needs and opportunities for advancing the utility of non-human primates as model organisms for psychiatric research.

\section{A Developmental Neurobiology of Key Non-Human Primate Species}

Studies of normative non-human primate postnatal brain development lag far behind efforts in rodents, resulting in significant gaps in information about progressive changes in structure and neurochemistry (Levitt, 2003; Pryce, 2008). Similarly, efforts to characterize gene expression patterns in primate brain are in relatively early stages (Pryce, 2008; Sabatini et al, 2007). Further research in the developmental neurobiology of the non-human primate is critically important to progress in efforts to examine the interaction of environment, developmental stage, and genes for modeling psychopathology.

\section{Standardization of Behavioral Testing}

Rodent behavioral research has made significant strides in developing standardized testing to ensure generalizability of findings across different species, strains, and laboratories (eg Crawley, 2003). Current primate developmental behavioral research often employs somewhat more idiosyncratic methods with little standardization between investigators. For example, what constitutes nursery rearing varies significantly between primate facilities and likely contributes to some of the variability in the literature. This is amplified by the protracted duration of infancy in primates compared to rodents, which provides many opportunities for unexpected environmental intrusions. Different adverse rearing protocols focus on different aspects of the rearing experience. It is difficult to differentiate post-separation rearing experience from the early distress of parental loss. Furthermore, as these experiences are often sustained for a long period of time it is often difficult to know if there are specific developmental periods that are more sensitive to manipulations than others. The brain lesion literature also 
suffers from a similar lack of specificity. Non-human primate developmental research would be well served by an effort to systematically operationalize adverse rearing experiences.

Although studies that focus on broadly defined social behavior are useful in that they allow maximal flexibility in identifying abnormal behavioral responses, they are limited in the extent to which they inform understanding of specific brain pathology. Experimental paradigms such as startle or attention-orienting tasks which focus on behavioral and cognitive processes mapped onto specific neural structures are much more likely to add to our understanding of the specific pathology that underlies emotional dysregulation in primate models.

To date, such paradigms are relatively sparse but nonhuman primates are capable of performing many of the specific tasks on which humans with disorders typically show deviant responses. Many of these paradigms are both repeatable and stable so probes could be carried out on the same individuals longitudinally. This would enable a better description at a behavioral level as to how pathologic processes emerge; it might also inform how specific brain structures interact across development to sustain behavioral abnormalities.

\section{Gene-Environment Interactions}

A second area where future non-human primate studies will likely make an important contribution is a greater understanding of the gene-environment link. The striking recent findings of the differential susceptibility that is conferred by variations in the serotonin transporter gene to early adversity (Barr et al, 2004a) emphasizes the importance of genetic-environment interaction in the emergence of psychiatric disease. Human-based studies have identified many other polymorphic genes as potential candidates for psychiatric vulnerability including the $\mu$-opioid receptor (Wand et al, 2002), brain-derived neurotrophic factor (Strauss et al, 2005), serotonin-1a receptor (Lemonde et al, 2003), vasopressin-1b receptor (Dempster et al, 2007), and various dopamine receptors such as COMT and DRD4 (Munafo et al, 2008; Williams et al, 2007) among many others. The genetic profile of non-human primates is easily obtainable but only rarely incorporated into study designs.

The combination of small sample sizes in most primate studies and low base rates of many of these variations often make it difficult to assess the impact of specific polymorphisms on primate behavior. However, routine screening at breeding facilities of select polymorphic genotypes has begun to facilitate the selection of appropriate samples. The three-way interaction between genotype, environment, and developmental timing is likely to have important implications for psychiatry (Barr et al, 2008; Kinnally et al, 2008; Reif et al, 2007). As key structures increasingly become the focus of psychopathology (such as amygdala and ventral prefrontal cortex), developing normative maps of not only genetic expression but the timing of genetic expression - when specific genes are turned on and off-might provide important clues as to the sensitivity to different types of environmental input. Furthermore, advances in molecular techniques may soon make it possible to apply genetic knockout technology to non-human primate models (Yang et al, 2008). This would enable activating or deactivating specific genes at different periods of development. This kind of technique will provide important information regarding the physiological cascade of events that takes place within the central nervous system over the course of development.

Finally, the rapidly advancing field of neuroimaging is increasingly incorporated into non-human primate-based studies of developmental psychopathology (Fox et al, 2008; Rilling et al, 2001). Although ethical considerations have constrained PET and MRI studies in developing humans, fewer restrictions apply to non-human primates. Indeed, there has been a rapid advance in techniques developed to permit imaging in awake animals. Consequently, both structural neuroimaging techniques, such as morphometric assessment and diffusion tensor imaging, and functional techniques such as fMRI are becoming increasingly common in primates (Hadj-Bouziane et al, 2008; Leopold and Maier, 2006; Logothetis et al, 1999; Petkov et al, 2008). Thus important information regarding developmental trajectories of specific neurochemical systems is remarkably accessible in monkeys. Novel contrast agents, such as manganese, which may signal functional activity and functional connectivity, are also on the horizon (Bock et al, 2008; Koretsky and Silva, 2004). Although performing neuroimaging in non-human primates presents a variety of challenges, it also affords the opportunity for much more control and better assessment than is typically available in human studies. This approach in particular opens remarkable opportunities to examine repeatedly the interaction of brain development and genotype over the course of an individual's development (Rogers et al, 2008).

\section{SUMMARY}

Non-human primate studies have made tremendous contributions to our understanding of the brain basis of behavior and biological underpinnings of psychiatric disease. Although there are clearly limitations to the scope of disease that non-human primate studies can model there is a niche that only primate-based studies can fill. Many experimental questions that focus on intricate social interactions, long-term development, and complex cognitive-affective interactions are best suited for primate studies. Non-human primate studies of emotional behavior have made tremendous contributions to our understanding of psychobiology and will certainly continue to inform future generations for many years to come. 


\section{ACKNOWLEDGEMENTS}

This work was supported by the NIMH Intramural Research Program.

\section{DISCLOSURE}

The authors have no conflicts of interest. Also, JTW declares that in the last 5 years he has received no support for activities other than those provided by the NIMH Intramural Research Program.

\section{REFERENCES}

Amaral DG, Bauman MD, Schumann CM (2003). The amygdala and autism: implications from non-human primate studies. Genes Brain Behav 2: 295-302.

Amiez C, Joseph JP, Procyk E (2006). Reward encoding in the monkey anterior cingulate cortex. Cereb Cortex 16: 1040-1055.

Anderson CO, Kenney AM, Mason WA (1977). Effects of maternal mobility, partner, and endocrine state on social responsiveness of adolescent rhesus monkeys. Dev Psychobiol 10: 421-434.

Andrews MW, Rosenblum LA (1991). Attachment in monkey infants raised in variable- and low-demand environments. Child Dev 62: 686-693.

Arseneault L, Milne BJ, Taylor A, Adams F, Delgado K, Caspi A et al (2008). Being bullied as an environmentally mediated contributing factor to children's internalizing problems: a study of twins discordant for victimization. Arch Pediatr Adolesc Med 162: 145-150.

Bachevalier J, Beauregard M, Alvarado MC (1999). Long-term effects of neonatal damage to the hippocampal formation and amygdaloid complex on object discrimination and object recognition in rhesus monkeys (Macaca mulatta). Behav Neurosci 113: 1127-1151

Bachevalier J, Brickson M, Hagger C, Mishkin M (1990). Age and sex differences in the effects of selective temporal lobe lesion on the formation of visual discrimination habits in rhesus monkeys (Macaca mulatta). Behav Neurosci 104: 885-899.

Bachevalier J, Malkova L (2006). The amygdala and development of social cognition: theoretical comment on Bauman, Toscano, Mason, Lavenex, and Amaral (2006). Behav Neurosci 120: 989-991.

Bailey JN, Breidenthal SE, Jorgensen MJ, McCracken JT, Fairbanks LA (2007). The association of DRD4 and novelty seeking is found in a nonhuman primate model. Psychiatr Genet 17: 23-27.

Beauregard M, Malkova L, Bachevalier J (1995). Stereotypes and loss of social affiliation after early hippocampectomy in primates. Neuroreport 6: 2521-2526.

Baron-Cohen S, Ring HA, Bullmore ET, Wheelwright S, Ashwin C, Williams SC (2000). The amygdala theory of autism. Neurosci Biobehav Rev 24: 355-364.

Barr CS, Newman TK, Becker ML, Parker CC, Champoux M, Lesch KP et al (2003). The utility of the non-human primate; model for studying gene by environment interactions in behavioral research. Genes Brain Behav 2: 336-340.

Barr CS, Newman TK, Lindell S, Shannon C, Champoux M, Lesch KP et al (2004a). Interaction between serotonin transporter gene variation and rearing condition in alcohol preference and consumption in female primates. Arch Gen Psychiatry 61: 1146-1152.

Barr CS, Newman TK, Schwandt M, Shannon C, Dvoskin RL, Lindell SG et al (2004b). Sexual dichotomy of an interaction between early adversity and the serotonin transporter gene promoter variant in rhesus macaques. Proc Natl Acad Sci USA 101: 12358-12363.

Barr CS, Newman TK, Shannon C, Parker C, Dvoskin RL, Becker ML et al (2004c). Rearing condition and rh5-HTTLPR interact to influence limbic-hypothalamicpituitary-adrenal axis response to stress in infant macaques. Biol Psychiatry 55: 733-738.

Barr CS, Schwandt M, Lindell SG, Chen SA, Goldman D, Suomi SJ et al (2007). Association of a functional polymorphism in the mu-opioid receptor gene with alcohol response and consumption in male rhesus macaques. Arch Gen Psychiatry 64: 369-376.

Barr CS, Schwandt ML, Lindell SG, Higley JD, Maestripieri D, Goldman D et al (2008). Variation at the mu-opioid receptor gene (OPRM1) influences attachment behavior in infant primates. Proc Natl Acad Sci USA 105: 5277-5281.

Bast T (2007). Toward an integrative perspective on hippocampal function: from the rapid encoding of experience to adaptive behavior. Rev Neurosci 18: 253-281.
Bastian ML, Sponberg AC, Sponberg AC, Suomi SJ, Higley JD (2003). Long-term effects of infant rearing condition on the acquisition of dominance rank in juvenile and adult rhesus macaques (Macaca mulatta). Dev Psychobiol 42: 44-51.

Bauman MD, Lavenex P, Mason WA, Capitanio JP, Amaral DG (2004a). The development of mother-infant interactions after neonatal amygdala lesions in rhesus monkeys. J Neurosci 24: 711-721.

Bauman MD, Lavenex P, Mason WA, Capitanio JP, Amaral DG (2004b). The development of social behavior following neonatal amygdala lesions in rhesus monkeys. J Cogn Neurosci 16: 1388-1411.

Bay KD, Beck P, Skinner RD, Garcia-Rill E (2007). GABAergic modulation of developing pedunculopontine nucleus. Neuroreport 18: 249-253.

Beauregard M, Malkova L, Bachevalier J (1995). Stereotypies and loss of social affiliation after early hippocampectomy in primates. Neuroreport 6: 2521-2526.

Bennett AJ, Lesch KP, Heils A, Long JC, Lorenz JG, Shoaf SE et al (2002). Early experience and serotonin transporter gene variation interact to influence primate CNS function. Mol Psychiatry 7: 118-122.

Bertolino A, Saunders RC, Mattay VS, Bachevalier J, Frank JA, Weinberger DR (1997). Altered development of prefrontal neurons in rhesus monkeys with neonatal mesial temporo-limbic lesions: a proton magnetic resonance spectroscopic imaging study. Cereb Cortex 7: 740-748.

Bethea CL, Pau FK, Fox S, Hess DL, Berga SL, Cameron JL (2005). Sensitivity to stress-induced reproductive dysfunction linked to activity of the serotonin system. Fertil Steril 83: 148-155.

Bethea CL, Streicher JM, Coleman K, Pau FK, Moessner R, Cameron JL (2004). Anxious behavior and fenfluramine-induced prolactin secretion in young rhesus macaques with different alleles of the serotonin reuptake transporter polymorphism (5HTTLPR). Behav Genet 34: 295-307.

Bock NA, Paiva FF, Nascimento GC, Newman JD, Silva AC (2008). Cerebrospinal fluid to brain transport of manganese in a non-human primate revealed by MRI. Brain Res 1198: 160-170.

Bower AJ (1990). Plasticity in the adult and neonatal central nervous system. $\mathrm{Br} J$ Neurosurg 4: 253-264.

Bowlby J (1973). Attachment and loss. Vol 3: Loss: Sadness and depression. Basic Books: New York. (reissued, 1999).

Brothers $L$ (1990). The social brain: a project for integrating primate behaviour and neurophysiology in a new domain. Concepts Neurosci 1: 27-51.

Buse E, Habermann G, Osterburg I, Korte R, Weinbauer GF (2003). Reproductive/ developmental toxicity and immunotoxicity assessment in the nonhuman primate model. Toxicology 185: 221-227.

Bush WW, Barr CS, Darrin EW, Shofer FS, Vite CH, Steinberg SA (2002). Results of cerebrospinal fluid analysis, neurologic examination findings, and age at the onset of seizures as predictors for results of magnetic resonance imaging of the brain in dogs examined because of seizures: 115 cases (1992-2000). J Am Vet Med Assoc 220: 781-784.

Cameron JL (2004). Interrelationships between hormones, behavior, and affect during adolescence: complex relationships exist between reproductive hormones, stress-related hormones, and the activity of neural systems that regulate behavioral affect. Comments on part III. Ann NY Acad Sci 1021: 134-142.

Capitanio JP, Mendoza SP, Mason WA, Maninger N (2005). Rearing environment and hypothalamic-pituitary-adrenal regulation in young rhesus monkeys (Macaca mulatta). Dev Psychobiol 46: 318-330.

Carr D, Sesack S (1996). Hippocampal afferents to the rat prefrontal cortex: synaptic targets and relation to dopaminergic terminals. J Comp Neurol 369: 1-15.

Carroll KA, Maestripieri D (1998). Infant abuse and neglect in monkeys-a discussion of definitions, epidemiology, etiology, and implications for child maltreatment: reply to Cicchetti (1998) and Mason (1998). Psychol Bull 123: 234-237.

Caspi A, Sugden K, Moffitt TE, Taylor A, Craig IW, Harrington H et al (2003). Influence of life stress on depression: moderation by a polymorphism in the 5 HTT gene. Science 301: 386-389.

Castner SA, Williams GV (2007). From vice to virtue: insights from sensitization in the nonhuman primate. Prog Neuropsychopharmacol Biol Psychiatry 31: 1572-1592.

Champoux M, Bennett A, Shannon C, Higley JD, Lesch KP, Suomi SJ (2002a). Serotonin transporter gene polymorphism, differential early rearing, and behavior in rhesus monkey neonates. Mol Psychiatry 7: 1058-1063.

Champoux M, Byrne E, DeLizio R, Suomi SJ (2002b). Motherless mothers revisited: rhesus maternal behavior and rearing history. Primates 33: 251-255.

Chen SW, Shemyakin A, Wiedenmayer CP (2006). The role of the amygdala and olfaction in unconditioned fear in developing rats. J Neurosci 26: 233-240.

Chudasama Y, Robbins TW (2006). Functions of frontostriatal systems in cognition: comparative neuropsychopharmacological studies in rats, monkeys and humans. Biol Psychol 73: 19-38.

Clarke AS, Hedeker DR, Ebert MH, Schmidt DE, McKinney WT, Kraemer GW (1996). Rearing experience and biogenic amine activity in infant rhesus monkeys. Biol Psychiatry 40: 338-352. 
Clarke AS, Kammerer CM, George KP, Kupfer DJ, McKinney WT, Spence MA et al (1995). Evidence for heritability of biogenic amine levels in the cerebrospinal fluid of rhesus monkeys. Biol Psychiatry 38: 572-577.

Clarke AS, Kraemer GW, Kupfer DJ (1998). Effects of rearing condition on HPA axis response to fluoxetine and desipramine treatment over repeated social separations in young rhesus monkeys. Psychiatry Res 79: 91-104.

Coe CL, Crispen HR (2000). Social stress in pregnant squirrel monkeys (Saimiri boliviensis peruviensis) differentially affects placental transfer of maternal antibody to male and female infants. Health Psychol 19: 554-559.

Coe CL, Kramer M, Czeh B, Gould E, Reeves AJ, Kirschbaum C et al (2003). Prenatal stress diminishes neurogenesis in the dentate gyrus of juvenile rhesus monkeys. Biol Psychiatry 54: 1025-1034.

Coe CL, Lulbach GR, Schneider ML (2002). Prenatal disturbance alters the size of the corpus callosum in young monkeys. Dev Psychobiol 41: 178-185.

Coplan JD, Andrews MW, Rosenblum LA, Owens MJ, Friedman S, Gorman JM et al (1996). Persistent elevations of cerebrospinal fluid concentrations of corticotropin-releasing factor in adult nonhuman primates exposed to early-life stressors: implications for the pathophysiology of mood and anxiety disorders. Proc Natl Acad Sci USA 93: 1619-1623.

Coplan JD, Rosenblum LA, Friedman S, Bassoff TB, Gorman JM (1992). Behavioral effects of oral yohimbine in differentially reared nonhuman primates. Neuropsychopharmacology 6: 31-37

Coplan JD, Trost RC, Owens MJ, Cooper TB, Gorman JM, Nemeroff CB et al (1998). Cerebrospinal fluid concentrations of somatostatin and biogenic amines in grown primates reared by mothers exposed to manipulated foraging conditions. Arch Gen Psychiatry 55: 473-477.

Crawley JN (2003). Behavioral phenotyping of rodents. Comp Med 53: 140-146.

Cryan JF, Thakker DR, Hoyer D (2007). Emerging use of non-viral RNA interference in the brain. Biochem Soc Trans 35: 411-415

Dempster EL, Burcescu I, Wigg K, Kiss E, Baji I, Gadoros J et al (2007). Evidence of an association between the vasopressin $\mathrm{V} 1 \mathrm{~b}$ receptor gene (AVPR1B) and childhood-onset mood disorders. Arch Gen Psychiatry 64: 1189-1195.

Denenberg VH (1999). Commentary: is maternal stimulation the mediator of the handling effect in infancy? Dev Psychobiol 34: 1-3.

Desmurget M, Turner RS (2008). Testing basal ganglia motor functions through reversible inactivations in the posterior internal globus pallidus. J Neurophysiol 99: 1057-1076.

Dettling AC, Feldon J, Pryce CR (2002a). Early deprivation and behavioral and physiological responses to social separation/novelty in the marmoset. Pharmacol Biochem Behav 73: 259-269.

Dettling AC, Feldon J, Pryce CR (2002b). Repeated parental deprivation in the infant common marmoset (Callithrix jacchus, primates) and analysis of its effects on early development. Biol Psychiatry 52: 1037-1046.

Dettling AC, Schnell CR, Maier C, Feldon J, Pryce CR (2007). Behavioral and physiological effects of an infant-neglect manipulation in a bi-parental, twinning primate: impact is dependent on familial factors. Psychoneuroendocrinology 32 331-349.

Donaldson ZR, Kondrashov FA, Putnam A, Bai Y, Stoinski TL, Hammock EA et al (2008). Evolution of a behavior-linked microsatellite-containing element in the 5' flanking region of the primate AVPR1A gene. BMC Evol Biol 8: 180.

Eichler EE, Zimmerman AW (2008). A hot spot of genetic instability in autism. N Engl J Med 358: 737-739.

Ellinwood Jr EH, Sudilovsky A, Nelson LM (1973). Evolving behavior in the clinical and experimental amphetamine (model) psychosis. Am J Psychiatry 130: 10881093

Ellison GD, Eison MS (1983). Continuous amphetamine intoxication: an animal model of the acute psychotic episode. Psychol Med 13: 751-761.

Emde RN, Polak PR, Spitz RA (1965). Anaclitic depression in an infant raised in an institution. J Am Acad Child Psychiatry 4: 545-553.

Eudey AA (1981). Ethical concerns in primate use and husbandry. Int J Study Anim Prob/ 2: 96-102.

Fahlke C, Lorenz JG, Long J, Champoux M, Suomi SJ, Higley JD (2000). Rearing experiences and stress-induced plasma cortisol as early risk factors for excessive alcohol consumption in nonhuman primates. Alcohol Clin Exp Res 24: 644-650.

Felger JC, Alagbe O, Hu F, Mook D, Freeman AA, Sanchez MM et al (2007). Effects of interferon-alpha on rhesus monkeys: a nonhuman primate model of cytokineinduced depression. Biol Psychiatry 62: 1324-1333.

Fox AS, Shelton SE, Oakes TR, Davidson RJ, Kalin NH (2008). Trait-like brain activity during adolescence predicts anxious temperament in primates. PLOS ONE 3: e2570.

Francis DD, Szegda K, Campbell G, Martin WD, Insel TR (2003). Epigenetic sources of behavioral differences in mice. Nat Neurosci 6: 445-446.

Gilmer WS, McKinney WT (2003). Early experience and depressive disorders: human and non-human primate studies. J Affect Disord 75: 97-113.
Giorgi D, Rouquier S (2002). Identification of V1R-like putative pheromone receptor sequences in non-human primates. Characterization of V1R pseudogenes in marmoset, a primate species that possesses an intact vomeronasal organ. Chem Senses 27: 529-537.

Gogtay N, Nugent III TF, Herman DH, Ordonez A, Greenstein D, Hayashi KM et al (2006). Dynamic mapping of normal human hippocampal development. Hippocampus 16: 664-672

Goldman PS (1976). The role of experience in recovery of function following orbita prefrontal lesions in infant monkeys. Neuropsychologia 14: 401-412.

Goldman PS (1978). Neuronal plasticity in primate telencephalon: anomalous projections induced by prenatal removal of frontal cortex. Science 202 768-770.

Goulet S, Dore FY, Murray EA (1998). Aspiration lesions of the amygdala disrupt the rhinal corticothalamic projection system in rhesus monkeys. Exp Brain Res 119: 131-140.

Goursaud AP, Bachevalier J (2007). Social attachment in juvenile monkeys with neonatal lesion of the hippocampus, amygdala and orbital frontal cortex. Behav Brain Res 176: 75-93.

Goursaud AP, Mendoza SP, Capitanio JP (2006). Do neonatal bilateral ibotenic acid lesions of the hippocampal formation or of the amygdala impair HPA axis responsiveness and regulation in infant rhesus macaques (Macaca mulatta)? Brain Res 1071: 97-104.

Haberny KA, Paule MG, Scallet AC, Sistare FD, Lester DS, Hanig JP et al (2002). Ontogeny of the $\mathrm{N}$-methyl-D-aspartate (NMDA) receptor system and susceptibility to neurotoxicity. Toxicol Sci 68: 9-17.

Hadj-Bouziane F, Bell AH, Knusten TA, Ungerleider LG, Tootell RB (2008). Perception of emotional expressions is independent of face selectivity in monkey inferior temporal cortex. Proc Natl Acad Sci USA 105: 5591-5596.

Harlow HF, Dodsworth RO, Harlow MK (1965). Total social isolation in monkeys. Proc Nal Acad Sci USA 54: 90-97.

Harlow HF, Mc Kinney Jr WT (1971). Nonhuman primates and psychoses. J Autism Child Schizophr 1: 368-375.

Heinz A, Higley JD, Gorey JG, Saunders RC, Jones DW, Hommer D et al (1998). In vivo association between alcohol intoxication, aggression, and serotonin transporter availability in nonhuman primates. Am J Psychiatry 155 1023-1028.

Heinz A, Jones DW, Gorey JG, Bennet A, Suomi SJ, Weinberger DR et al (2003). Serotonin transporter availability correlates with alcohol intake in non-human primates. Mol Psychiatry 8: 231-234.

Heinz A, Saunders RC, Kolachana BS, Jones DW, Gorey JG, Bachevalier J et al (1999). Striatal dopamine receptors and transporters in monkeys with neonatal temporal limbic damage. Synapse 32: 71-79.

Heiss JD, Walbridge S, Morrison P, Hampton RR, Sato S, Vortmeyer A et al (2005). Local distribution and toxicity of prolonged hippocampal infusion of muscimol. $J$ Neurosurg 103: 1035-1045.

Higley J, Hasert M, Suomi S, Linnoila M (1998). The serotonin reuptake inhibitor sertraline reduces excessive alcohol consumption in nonhuman primates: effect of stress. Neuropsychopharmacology 18: 431-443.

Higley JD, Suomi SJ, Linnoila M (1991). CSF monoamine metabolite concentrations vary according to age, rearing, and sex, and are influenced by the stressor of social separation in rhesus monkeys. Psychopharmacology (Berl) 103 551-556.

Higley JD, Suomi SJ, Linnoila M (1992). A longitudinal assessment of CSF monoamine metabolite and plasma cortisol concentrations in young rhesus monkeys. Biol Psychiatry 32: 127-145.

Hofer MA (1996). On the nature and consequences of early loss. Psychosom Med 58: $570-581$.

Insel TR, Scanlan J, Champoux M, Suomi SJ (1988). Rearing paradigm in a nonhuman primate affects response to beta-CCE challenge. Psychopharmacology (Berl) 96: 81-86.

Izquierdo A, Newman TK, Higley JD, Murray EA (2007). Genetic modulation of cognitive flexibility and socioemotional behavior in rhesus monkeys. Proc Nat Acad Sci USA 104: 14128-14133.

Jay T, Glowinski J, Thierry A (1989). Selectivity of the hippocampal projection to the prelimbic area of the prefrontal cortex in the rat. Brain Res 505: 337-340

Kaldy Z, Sigala N (2004). The neural mechanisms of object working memory: what is where in the infant brain? Neurosci Biobehav Rev 28: 113-121.

Kappel S, Matthess Y, Kaufmann M, Strebhardt K (2007). Silencing of mammalian genes by tetracycline-inducible shRNA expression. Nat Protoc 2: 3257-3269.

Kaufman IC, Rosenblum LA (1967a). Depression in infant monkeys separated from their mothers. Science 155: 1030-1031.

Kaufman IC, Rosenblum LA (1967b). The reaction to separation in infant monkeys: anaclitic depression and conservation-withdrawal. Psychosom Med 29: 648-675 
Kinnally EL, Lyons LA, Abel K, Mendoza S, Capitanio JP (2008). Effects of early experience and genotype on serotonin transporter regulation in infant rhesus macaques. Genes Brain Behav 7: 481-486.

Kirsch P, Esslinger C, Chen Q, Mier D, Lis S, Siddhanti S et al (2005). Oxytocin modulates neural circuitry for social cognition and fear in humans. J Neurosci 25: 11489-11493.

Kling A (1974). Differential effects of amygdalectomy in male and female nonhuman primates. Arch Sex Behav 3: 129-134.

Kling A, Green PC (1967). Effects of neonatal amygdalectomy in the maternally reared and maternally deprived monkey. Nature 213: 742-743.

Koretsky AP, Silva AC (2004). Manganese-enhanced magnetic resonance imaging (MEMRI). NMR Biomed 17: 527-531.

Kozorovitskiy Y, Gould E (2004). Dominance hierarchy influences adult neurogenesis in the dentate gyrus. J Neurosci 24: 6755-6759.

Kraemer GW, Moore CF, Newman TK, Barr CS, Schneider ML (2008). Moderate level fetal alcohol exposure and serotonin transporter gene promoter polymorphism affect neonatal temperament and limbic-hypothalamic-pituitaryadrenal axis regulation in monkeys. Biol Psychiatry 63: 317-324.

Kraemer GW, Schmidt DE, Ebert MH (1997). The behavioral neurobiology of selfinjurious behavior in rhesus monkeys. Current concepts and relations to impulsive behavior in humans. Ann NY Acad Sci 836: 12-38.

Kumar P, Wu H, McBride JL, Jung KE, Kim MH, Davidson BL et al (2007). Transvascular delivery of small interfering RNA to the central nervous system. Nature 448: 39-43.

Lam JA, Rosenheck R (1999). Social support and service use among homeless persons with serious mental illness. Int J Soc Psychiatry 45: 13-28.

Lavenex P, Banta Lavenex P, Amaral DG (2007a). Postnatal development of the primate hippocampal formation. Dev Neurosci 29: 179-192.

Lavenex P, Lavenex PB, Amaral DG (2007b). Spatial relational learning persists following neonatal hippocampal lesions in macaque monkeys. Nat Neurosci 10: 234-239.

Lemonde S, Turecki G, Bakish D, Du L, Hrdina PD, Bown CD et al (2003). Impaired repression at a 5-hydroxytryptamine $1 \mathrm{~A}$ receptor gene polymorphism associated with major depression and suicide. J Neurosci 23: 8788-8799.

Leopold DA, Maier A (2006). Neuroimaging: perception at the brain's core. Curr Biol 16: R95-R98.

Lesch KP, Meyer J, Glatz K, Flugge G, Hinney A, Hebebrand J et al (1997). The 5-HT transporter gene-linked polymorphic region (5-HTTLPR) in evolutionary perspective: alternative biallelic variation in rhesus monkeys. Rapid communication. J Neural Transm 104: 1259-1266.

Levine S (2000). Influence of psychological variables on the activity of the hypothalamic-pituitary-adrenal axis. Eur J Pharmacol 405: 149-160.

Levine S, Mody T (2003). The long-term psychobiological consequences of intermittent postnatal separation in the squirrel monkey. Neurosci Biobehav Rev 27: 83-89.

Levitt $P$ (2003). Structural and functional maturation of the developing primate brain. $J$ Pediatr 143: S35-S45.

Lewis DA (1997). Development of the prefrontal cortex during adolescence: insights into vulnerable neural circuits in schizophrenia. Neuropsychopharmacology 16: 385-398.

Lipska B, Chrapusta S, Egan M, Weinberger D (1995). Neonatal excitotoxic ventral hippocampal damage alters dopamine response to mild chronic stress and haloperidol treatment. Synapse 20: 125-130.

Lipska BK, Halim ND, Segal PN, Weinberger DR (2002). Effects of reversible inactivation of the neonatal ventral hippocampus on behavior in the adult rat. J Neurosci 22: 2835-2842.

Lipska BK, Weinberger DR (2000). To model a psychiatric disorder in animals: schizophrenia as a reality test. Neuropsychopharmacology 23: 223-239.

Logothetis NK (2008). What we can do and what we cannot do with fMRI. Nature 453: 869-878.

Logothetis NK, Guggenberger H, Peled S, Pauls J (1999). Functional imaging of the monkey brain. Nat Neurosci 2: 555-562.

Lutz C, Well A, Novak M (2003). Stereotypic and self-injurious behavior in rhesus macaques: a survey and retrospective analysis of environment and early experience. Am J Primatol 60: 1-15.

Lyons DM, Parker KJ (2007). Stress inoculation-induced indications of resilience in monkeys. J Trauma Stress 20: 423-433.

Lyons DM, Yang C, Mobley BW, Nickerson JT, Schatzberg AF (2000). Early environmental regulation of glucocorticoid feedback sensitivity in young adult monkeys. J Neuroendocrinol 12: 723-728.

Machado CJ, Bachevalier J (2003). Non-human primate models of childhood psychopathology: the promise and the limitations. J Child Psychol Psychiatry 44: 64-87.

Machiyama $Y$ (1992). Chronic methamphetamine intoxication model of schizophrenia in animals. Schizophr Bull 18: 107-113.
Maestripieri D (1998). Parenting styles of abusive mothers in group-living rhesus macaques. Anim Behav 55: 1-11.

Maestripieri D (2005). Early experience affects the intergenerational transmission of infant abuse in rhesus monkeys. Proc Natl Acad Sci USA 102: 9726-9729.

Maestripieri D (2007). Macachiavellian Intelligence. How Rhesus Macaques and Humans have Conquered the World. University of Chicago Press: London.

Maestripieri D, Lindell SG, Ayala A, Gold PW, Higley JD (2005). Neurobiological characteristics of rhesus macaque abusive mothers and their relation to social and maternal behavior. Neurosci Biobehav Rev 29: 51-57.

Maestripieri D, McCormack K, Lindell SG, Higley JD, Sanchez MM (2006). Influence of parenting style on the offspring's behaviour and CSF monoamine metabolite levels in crossfostered and noncrossfostered female rhesus macaques. Behav Brain Res 175: 90-95.

McCorkle BH, Rogers ES, Dunn EC, Lyass A, Wan YM (2008). Increasing social support for individuals with serious mental illness: evaluating the compeer model of intentional friendship. Community Ment Health $J$ [E-pub ahead of print].

McManus EM (1996). Health promotion and social support for community-based clients with chronic mental illness. Nursingconnections 9: 49-55.

Meaney MJ, Diorio J, Francis D, Widdowson J, LaPlante P, Caldji C et al (1996). Early environmental regulation of forebrain glucocorticoid receptor gene expression: implications for adrenocortical responses to stress. Dev Neurosci 18: 49-72.

Meyer-Lindenberg A, Hariri AR, Munoz KE, Mervis CB, Mattay VS, Morris CA et al (2005). Neural correlates of genetically abnormal social cognition in Williams syndrome. Nat Neurosci 8: 991-993.

Miller EA, Goldman PS, Rosvold HE (1973). Delayed recovery of function following orbital prefrontal lesions in infant monkeys. Science 182: 304-306.

Miller-Butterworth CM, Kaplan JR, Barmada MM, Manuck SB, Ferrell RE (2007). The serotonin transporter: sequence variation in Macaca fascicularis and its relationship to dominance. Behav Genet 37: 678-696.

Miska EA, Alvarez-Saavedra E, Townsend M, Yoshii A, Sestan N, Rakic P et al (2004). Microarray analysis of microRNA expression in the developing mammalian brain. Genome Biol 5: R68.

Munafo MR, Yalcin B, Willis-Owen SA, Flint J (2008). Association of the dopamine D4 receptor (DRD4) gene and approach-related personality traits: meta-analysis and new data. Biol Psychiatry 63: 197-206.

Murray EA, O'Doherty JP, Schoenbaum G (2007). What we know and do not know about the functions of the orbitofrontal cortex after 20 years of cross-species studies. J Neurosci 27: 8166-8169.

Nemeroff CB (2004). Neurobiological consequences of childhood trauma. J Clin Psychiatry 65(Suppl 1): 18-28.

Newman TK, Syagailo YV, Barr CS, Wendland JR, Champoux M, Graessle M et al (2005). Monoamine oxidase A gene promoter variation and rearing experience influences aggressive behavior in rhesus monkeys. Biol Psychiatry 57: 167-172.

Ono S, Mustari MJ (2007). Horizontal smooth pursuit adaptation in macaques after muscimol inactivation of the dorsolateral pontine nucleus (DLPN). J Neurophysiol 98: 2918-2932.

Orban GA, Van Essen D, Vanduffel W (2004). Comparative mapping of higher visual areas in monkeys and humans. Trends Cogn Sci 8: 315-324.

Palit G, Kumar R, Chowdhury SR, Gupta MB, Saxena RC, Srimal RC et al (1998). A primate model of anxiety. Eur Neuropsychopharmacol 8: 195-201.

Parker KJ, Buckmaster CL, Justus KR, Schatzberg AF, Lyons DM (2005). Mild early life stress enhances prefrontal-dependent response inhibition in monkeys. Biol Psychiatry 57: 848-855.

Parker KJ, Buckmaster CL, Sundlass K, Schatzberg AF, Lyons DM (2006). Maternal mediation, stress inoculation, and the development of neuroendocrine stress resistance in primates. Proc Natl Acad Sci USA 103: 3000-3005.

Parker KJ, Rainwater KL, Buckmaster CL, Schatzberg AF, Lindley SE, Lyons DM (2007). Early life stress and novelty seeking behavior in adolescent monkeys. Psychoneuroendocrinology 32: 785-792.

Parr LA, Winslow JT, Davis M (2002). Rearing experience differentially affects somatic and cardiac startle responses in rhesus monkeys (Macaca mulatta). Behav Neurosci 116: 378-386.

Paule MG (2005). Chronic drug exposures during development in nonhuman primates: models of brain dysfunction in humans. Front Biosci 10: 2240-2249.

Petkov Cl, Kayser C, Steudel T, Whittingstall K, Augath M, Logothetis NK (2008). A voice region in the monkey brain. Nat Neurosci 11: 367-374.

Pine DS, Cohen JA (2002). Trauma in children and adolescents: risk and treatment of psychiatric sequelae. Biol Psychiatry 51: 519-531.

Pryce CR (2008). Postnatal ontogeny of expression of the corticosteroid receptor genes in mammalian brains: inter-species and intra-species differences. Brain Res Rev 57: 596-605.

Pryce CR, Dettling AC, Spengler M, Schnell CR, Feldon J (2004). Deprivation of parenting disrupts development of homeostatic and reward systems in marmoset monkey offspring. Biol Psychiatry 56: 72-79. 
Pryce CR, Ruedi-Bettschen D, Dettling AC, Weston A, Russig H, Ferger B et al (2005). Long-term effects of early-life environmental manipulations in rodents and primates: potential animal models in depression research. Neurosci Biobehav Rev 29: 649-674.

Putzhammer A, Schoeler A, Rohrmeier T, Sand P, Hajak G, Eichhammer P (2005). Evidence of a role for the 5-HTTLPR genotype in the modulation of motor response to antidepressant treatment. Psychopharmacology (Berl) 178: 303-308.

Quigley M (2007). Non-human primates: the appropriate subjects of biomedical research? J Med Ethics 33: 655-658.

Reif A, Rosler M, Freitag CM, Schneider M, Eujen A, Kissling C et al (2007). Nature and nurture predispose to violent behavior: serotonergic genes and adverse childhood environment. Neuropsychopharmacology 32: 2375-2383.

Rice DC (2000). Parallels between attention deficit hyperactivity disorder and behavioral deficits produced by neurotoxic exposure in monkeys. Environ Health Perspect 108(Suppl 3): 405-408.

Rilling JK, Winslow JT, O'Brien D, Gutman DA, Hoffman JM, Kilts CD (2001) Neural correlates of maternal separation in rhesus monkeys. Biol Psychiatry 49 146-157.

Rogers J, Shelton SE, Shelledy W, Garcia R, Kalin NH (2008). Genetic influences on behavioral inhibition and anxiety in juvenile rhesus macaques. Genes Brain Behav 7: 463-469.

Rosenblum LA, Andrews MW (1994). Influences of environmental demand on maternal behavior and infant development. Acta Paediatr Supp/ 397: 57-63.

Rosenblum LA, Coplan JD, Friedman S, Bassoff T (1991). Dose-response effects of oral yohimbine in unrestrained primates. Biol Psychiatry 29: 647-657.

Rosenblum LA, Coplan JD, Friedman S, Bassoff T, Gorman JM, Andrews MW (1994). Adverse early experiences affect noradrenergic and serotonergic functioning in adult primates. Biol Psychiatry 35: 221-227.

Rutter M, O'Connor TG (2004). Are there biological programming effects for psychological development? Findings from a study of Romanian adoptees. Dev Psychol 40: 81-94.

Sabatini MJ, Ebert P, Lewis DA, Levitt P, Cameron JL, Mirnics K (2007). Amygdala gene expression correlates of social behavior in monkeys experiencing maternal separation. J Neurosci 27: 3295-3304.

Sahay A, Hen R (2008). Hippocampal neurogenesis and depression. Novartis Found Symp 289: 152-160; discussion 160-164, 193-195.

Salahpour A, Medvedev IO, Beaulieu JM, Gainetdinov RR, Caron MG (2007). Local knockdown of genes in the brain using small interfering RNA: a phenotypic comparison with knockout animals. Biol Psychiatry 61: 65-69.

Sams-Dodd F, Newman JD (1997). Effects of administration regime on the psychotomimetic properties of d-amphetamine in the squirrel monkey (Saimir sciureus). Pharmacol Biochem Behav 56: 471-480.

Sanchez MM (2006). The impact of early adverse care on HPA axis development nonhuman primate models. Horm Behav 50: 623-631.

Sanchez MM, Alagbe O, Felger JC, Zhang J, Graff AE, Grand AP et al (2007). Activated p38 MAPK is associated with decreased CSF 5-HIAA and increased maternal rejection during infancy in rhesus monkeys. Mol Psychiatry 12: 895-897.

Sanchez MM, Noble PM, Lyon CK, Plotsky PM, Davis M, Nemeroff CB et al (2005). Alterations in diurnal cortisol rhythm and acoustic startle response in nonhuman primates with adverse rearing. Biol Psychiatry 57: 373-381.

Saunders RC, Aigner TG, Frank JA (1990). Magnetic resonance imaging of the rhesus monkey brain: use for stereotactic neurosurgery. Exp Brain Res 81: 443-446.

Saunders RC, Kolachana BS, Bachevalier J, Weinberger DR (1998). Neonata lesions of the medial temporal lobe disrupt prefrontal cortical regulation of striatal dopamine. Nature 393: 169-171.

Schlemmer RF, Davis JM (1986). A primate model for the study of hallucinogens. Pharmacol Biochem Behav 24: 381-392.

Seay B, Harlow HF (1965). Maternal separation in the rhesus monkey. J Nerv Ment Dis 140: 434-441.

Selemon LD, Begovic A, Goldman-Rakic PS, Castner SA (2007). Amphetamine sensitization alters dendritic morphology in prefrontal cortical pyramidal neurons in the non-human primate. Neuropsychopharmacology 32: 919-931.

Shannon C, Schwandt ML, Champoux M, Shoaf SE, Suomi SJ, Linnoila M et al (2005). Maternal absence and stability of individual differences in CSF 5-HIAA concentrations in rhesus monkey infants. Am J Psychiatry 162 1658-1664.

Siebert S, Jurgens U (2003). Vocalization after periaqueductal grey inactivation with the GABA agonist muscimol in the squirrel monkey. Neurosci Lett 340: 111-114.

Smith EL, Batuman OA, Coplan JD, Rosenblum LA (2001). Stress, peer affiliation, and transforming growth factor-beta1 in differentially reared primates. CNS Spectr 6: 573-578.

Spinelli S, Schwandt ML, Lindell SG, Newman TK, Heilig M, Suomi SJ et al (2007). Association between the recombinant human serotonin transporter linked promoter region polymorphism and behavior in rhesus macaques during a separation paradigm. Dev Psychopathol 19: 977-987.
Spitz RA (1952). Infantile depression and the general adaptation syndrome; on the relation between physiologic model and psychoanalytic conceptualization. Proc Annu Meet Am Psychopathol Assoc 12: 93-108.

Strauss J, Barr CL, George CJ, Devlin B, Vetro A, Kiss E et al (2005). Brain-derived neurotrophic factor variants are associated with childhood-onset mood disorder: confirmation in a Hungarian sample. Mol Psychiatry 10: 861-867.

Suomi SJ (1991). Early stress and adult emotional reactivity in rhesus monkeys. Ciba Found Symp 156: 171-183; discussion 183-188.

Suomi SJ (1997). Early determinants of behaviour: evidence from primate studies. Br Med Bull 53: 170-184.

Swiss Committee on Animal Experiments (2006). 'Research on primates - an ethical evaluation'. Altex 23: 169-178, 159-168

Szyf M, Weaver I, Meaney M (2007). Maternal care, the epigenome and phenotypic differences in behavior. Reprod Toxicol 24: 9-19.

Thompson A, Boekhoorn K, Van Dam AM, Lucassen PJ (2008). Changes in adult neurogenesis in neurodegenerative diseases: cause or consequence? Genes Brain Behav 7(Suppl 1): 28-42.

Thompson Cl (1981). Learning in rhesus monkeys after amygdalectomy in infancy or adulthood. Behav Brain Res 2: 81-101.

Thompson Cl, Bergland RM, Towfighi JT (1977). Social and nonsocial behaviors of adult rhesus monkeys after amygdalectomy in infancy or adulthood. J Comp Physiol Psychol 91: 533-548.

Thompson Cl, Schwartzbaum JS, Harlow HF (1969). Development of social fear after amygdalectomy in infant rhesus monkeys. Physiol Behav 4: 249-254.

Thompson Cl, Towfighi JT (1976). Social behavior of juvenile rhesus monkeys after amygdalectomy in infancy. Physiol Behav 17: 831-836.

Thorne BM (1972). Brain lesions and affective behavior in primates: a selected review. J Gen Psychol 86: 153-162.

Tsankova N, Renthal W, Kumar A, Nestler EJ (2007). Epigenetic regulation in psychiatric disorders. Nat Rev Neurosci 8: 355-367.

Vellucci SV, Herbert J, Keverne EB (1986). The effect of midazolam and betacarboline carboxylic acid ethyl ester on behaviour, steroid hormones and centra monoamine metabolites in social groups of talapoin monkeys. Psychopharmacology (Berl) 90: 367-372.

Wallen K (1996). Nature needs nurture: the interaction of hormonal and social influences on the development of behavioral sex differences in rhesus monkeys. Horm Behav 30: 364-378.

Wallen K, Goldfoot DA, Goy RW (1981). Peer and maternal influences on the expression of foot-clasp mounting by juvenile male rhesus monkeys. Dev Psychobiol 14: 299-309.

Wand GS, McCaul M, Yang X, Reynolds J, Gotjen D, Lee S et al (2002). The muopioid receptor gene polymorphism (A118G) alters HPA axis activation induced by opioid receptor blockade. Neuropsychopharmacology 26: 106-114.

Weaver A, de Waal FB (2003). The mother-offspring relationship as a template in social development: reconciliation in captive brown capuchins (Cebus apella). $J$ Comp Psychol 117: 101-110.

Weaver IC, Cervoni N, Champagne FA, D'Alessio AC, Sharma S, Seckl JR et al (2004). Epigenetic programming by maternal behavior. Nat Neurosci 7 847-854

Weerts EM, Tornatzky W, Miczek KA (1993). 'Anxiolytic' and 'anxiogenic' benzodiazepines and beta-carbolines: effects on aggressive and social behavior in rats and squirrel monkeys. Psychopharmacology (Berl) 110: 451-459.

Wellman LL, Gale K, Malkova L (2005). GABAA-mediated inhibition of basolatera amygdala blocks reward devaluation in macaques. J Neurosci 25: 4577-4586.

Wendland JR, Lesch KP, Newman TK, Timme A, Gachot-Neveu H, Thierry B et al (2006). Differential functional variability of serotonin transporter and monoamine oxidase a genes in macaque species displaying contrasting levels of aggressionrelated behavior. Behav Genet 36: 163-172.

Williams HJ, Owen MJ, O'Donovan MC (2007). Is COMT a susceptibility gene for schizophrenia? Schizophr Bull 33: 635-641.

Winslow JT (2005). Neuropeptides and non-human primate social deficits associated with pathogenic rearing experience. Int J Dev Neurosci 23: 245-251.

Winslow JT, Noble PL, Lyons CK, Sterk SM, Insel TR (2003). Rearing effects on cerebrospinal fluid oxytocin concentration and social buffering in rhesus monkeys. Neuropsychopharmacology 28: 910-918.

Wu J, Basha MR, Brock B, Cox DP, Cardozo-Pelaez F, McPherson CA et al (2008). Alzheimer's disease (AD)-like pathology in aged monkeys after infantile exposure to environmental metal lead $(\mathrm{Pb})$ : evidence for a developmental origin and environmental link for AD. J Neurosci 28: 3-9.

Yang $\mathrm{SH}$, Cheng PH, Banta H, Piotrowska-Nitsche K, Yang JJ, Cheng EC et al (2008). Towards a transgenic model of Huntington's disease in a non-human primate. Nature 453: 921-924.

Zhang TY, Bagot R, Parent C, Nesbitt C, Bredy TW, Caldji C et al (2006). Maternal programming of defensive responses through sustained effects on gene expression. Biol Psychol 73: 72-89. 


\section{APPENDIX 1}

\section{Old World Rhesus Macaque}

Suborder: Haplorrhini; Infraorder: Simiiformes; Superfamily: Cercopithecoidea; Family: Cercopithecidae; Subfamily: Cercopithecinae; Genus: Macaca; Species: mulatta.

Rhesus macaques live in large, multi-male/multi-female groups.

Females remain in their natal groups and form dominance hierarchies according to their matrilineal kinship; males emigrate from their natal groups at the beginning of the breeding shortly before puberty, and may transfer groups throughout their lives.

Gestation lasts 164 days in rhesus macaques and the interbirth interval is between 12 and 24 months.

Although the majority of parental care is the responsibility of the mother, rhesus infants are also handled by close female relatives and protected by adult males. In the first few days, the infant is carried ventrally and protected from other group members by the mother. Rhesus infants begin to ride dorsally for short periods during the second week. By 6 weeks of age, locomotor skills are developed enough for the infant to move independently. Young rhesus macaques are fully weaned by the birth of their next sibling. Exploration off of the mother begins as early as five days old and continues to increase so that by the third week, the infant breaks physical contact with the mother as frequently as possible.

Females reach puberty around age of 3 years whereas males are sexually mature by age of 4 years. The ovarian cycle lasts for 28 days. Estrus lasts for 8-12 days, with the day of ovulation occurring at the midpoint of the estrus period. Females reproduce from 3 years until about 20 years of age. During this time between becoming sexually mature and when they begin to mate, young rhesus macaques are learning the social skills, including fighting ability, which will influence their success throughout their lives. Adapted from: Cawthon Lang KA. 2005 July 20. Primate fact sheets: Rhesus macaque (Macaca mulatta) Taxonomy, Morphology, and Ecology.

$\langle$ http://pin.primate.wisc.edu/factsheets/entry/rhesus macaque $\rangle$. Accessed on 16 March 2008.

\section{APPENDIX 2}

\section{Common Marmoset}

Suborder: Haplorrhini; Infraorder: Simiiformes; Family: Cebidae; Subfamily: Callitrichinae; Genus: Callithrix; Subgenus: Callithrix; Species: jacchus.

Groups of common marmosets range in size from 3 to 15 animals. Members of this group have a tendency to give birth to nonidentical twins. The average lifespan of a wild common marmoset is 12 years.

Social structure revolves around a stable, extended family unit with a few dominant breeding individuals and flexible mating behavior. Within the group, three generations are often encompassed including one or two breeding females with one breeding male and related adults (possibly parents or siblings) and the breeding pairs' offspring. One of the defining social behaviors of common marmosets is their system of cooperative breeding and infant care.

Menarche occurs between 9 and 14 months of age but common marmosets do not menstruate. The ovarian cycle lasts between 24 and 30 days, but averages 28 days. Gestation lasts about 5 months, and soon after parturition (within 10 days) female marmosets begin to cycle again and shortly thereafter become pregnant. From birth, common marmosets have a very strong cling reflex and do not voluntarily leave their carrier's back for the first 2 weeks of life. They are very active starting in the second week and investigating their surroundings.

Immediately after birth, the breeding male and presumptive father of the infants begins to carry the twins and care giving is offered by the father, mother, or other members of the group.

Over the following weeks, time off the backs of carriers gradually increases and the infants develop locomotor behaviors and coordination and begin to exhibit play behavior. By about 3 months of age, the infants are almost completely weaned and are capable of selffeeding.

By 15 months, common marmosets have reached their adult weight and are capable of reproduction but do not reproduce until social conditions are adequate. Adapted from: Cawthon Lang KA, 20 July 2005. Primate fact sheets: Rhesus macaque (Macaca mulatta) Taxonomy, Morphology, and Ecology.

$\langle$ http://pin.primate.wisc.edu/factsheets/entry/rhesus_ macaque $\rangle$. Accessed on 16 March 2008. 